\title{
Implementasi Sistem Informasi Akuntansi Untuk Menunjang Kinerja Keuangan Pada Forum Umkm Pasaman Barat
}

\author{
Desi Permata Sari, Hadi Syahputra, Rahmatul Husna Arsyah \\ Universitas Putra Indonesia "YPTK" Padang, Indonesia \\ Email : Desipermatasari735@gmail.com
}

\begin{abstract}
Abstrak
Tujuan dari penelitian ini untuk menganalisis bagaimana implementasi sistem informasi akuntansi untuk menunjang kinerja keuangan pada Forum UMKM Pasaman Barat. Populasi dalam penelitian ini adalah seluruh anggota Forum UMKM berjumlah 100 anggota.. Sampel yang digunakan 30 responden, metode analisis yang digunakan adalah metode analisis deskriptif, teknik pengambilan sampel Purposive sampel. Berdasarkan hasil penelitian yang dilakukan menunjukan bahwa penerapan Sistem Informasi Akuntansi di Forum UMKM belum maksimal, diketahui bahwa hanya sedikit bagi Anggota Forum UMKM yang menggunakan software sistem informasi keuangan menggunakan Ms. Office khususnya Ms. Excel, bahkan masih banyak yang mengunakan manual book atau pencatatan dilakukan di dalam buku saja. Dimulai dari pencatatan sistem penjualan dan juga pembelian. Sehingga peneliti mengambil solusi untuk menggunakan bahasa pemrograman visual basic dalam bentuk aplikasi SIA.
\end{abstract}

Kata kunci: SIA, Akuntansi, UMKM

\section{Pendahuluan}

Persaiangan dalam dunia usaha pun menjadikan sistem informasi akuntansi dalam dunia bisnis menjadi sebuah kebutuhan. Penggunaan sistem informasi akuntansi tentunya menjadikan pekerjaan lebih mudah dan lebih efisian sehingga ketika kita memerlukan informasi maka akan lebih cepat dan menghemat waktu. Hal ini tentu juga dirasakan oleh Usaha Kecil dan Menengah (UMKM). Usaha Mikro, Kecil dan Menengah (UMKM) merupakan salah satu penggerak perekonomian rakyat yang tangguh. Usaha Mikro Kecil Menengah (UMKM) mempunyai peranan yang penting dalam pertumbuhan ekonomi dan industri suatu negara, suatu badan usaha khususnya UMKM dituntut untuk melakukan perubahan guna meningkatkan daya saingnya, hal ini karena banyak dari para pengusaha kecil dan menengah berangkat dari industri keluarga / rumahan sehingga pengelolaanya tidak dimanajemen dengan baik.

Usaha Kecil dan Menengah (UKM) mampu berperan sebagai pendorong pembangunan ekonomi suatu Negara terkhususnya dalam penelitian ini untuk Kabupaten Pasaman Barat. Ada beberapa contoh sektor unggulan yang dipastikan mampu menopang perekonomian Kabupaten Pasaman Barat tersebut merupakan UMKM di bidang industri kreatif seperti kuliner kerajinan.

Perkembangan teknologi informasi (TI) telah mengubah cara dan peta bisnis dunia.(Awaludin, 2015), menyatakan adopsi TIK bisa membantu bisnis semakin efesien. Teknologi informasi menyediakan berbagai macam media yang bisa digunakan untuk menampilkan informasi. Dalam bidang usaha, perkembangan teknologi informasi telah memberikan dampak yang cukup berarti untuk meningkatkan kegiatan usaha, khususnya dalam hal manajemen pemasaran atau promosi. 
Menurut (Al, 2012) teknologi informasi pada beberapa tahun lalu hanya dapat dijangkau oleh perusahaan besar, namun sekarang telah dapat digunakan oleh UKM, sebagai sarana untuk meningkatkan keunggulan kompetitif mereka.Dalam suatu perusahaan, diperlukan adanya pencatatan dan pelaporan untuk menilai kinerja perusahaan tersebut. Menurut (Suryo, 2008) selain modal dan akses pasar yang dapat menyulitkan Usaha Mikro, Kecil, dan Menengah (UMKM) untuk berkembang, banyak UMKM tidak mampu menjadi besar karena tidak memiliki pembukuan yang sistematis, akibatnya tidak ada pemilihan tegas antara uang pribadi dan uang perusahaan. Sistem informasi akuntansi (SIA) menghasilkan informasi akuntansi yang sangat diperlukan oleh pihak manajemen perusahaan dalam merumuskan berbagai keputusan dalam memecahkan permasalahan yang dihadapi perusahaan (Fitriyah, 2006)

Penggunaan sistem informasi akuntansi berbasis komputer diharapkan dapat membantu UMKM dalam menyusun laporan keuangan dengan mudah sehingga akan mempermudah dalam memperoleh modal dari lembaga keuangan dan dapat meningkatkan kinerja keuangan UKM.. Penelitian yang dilakukan oleh (Riza \& Maresti, 2020) setelah melakukan penelitian hasilnya bahwa pada usaha mikro khususnya Lembaga Bimbingan Belajar yang ada di Sumatra Barat masih minim dalam sistem informasi akuntansi dalam mengelola keuangan usahanya. Selanjutnya penelitian yang dilakukan oleh (Rahmawati, 2019) bahwa penerapan dan kesiapan dari sistem informasi akuntansi masih belum sejalan dengan revolusi industri.

Selanjutnya penelitian yang dilakukan oleh (Argacia, Sugiarti, \& Harindahyani, 2019), bahwa menggunakan sistem akuntansi berbasis computer UKM Sambal DDI dapat menyediakan informasi keuangan lebih cepat dan tepat serta menghasilkan informasi yang menggambarkan kinerja keungan yang bermanfaat dalam keputusan seperti efisiensi biaya dan penetapan harga jual. Penelitian (Bachtiar, 2014), bahwa UKM belum menggunakan sistem informasi akuntansi sehingga kurang mmpu berkembang. Kemudian penelitian (Suharnato, 2018) Hasil dari penelitian ini ditemukan masih memerlukan pendampingan serta penguatan penguasaan operator dalam menjalankan sistem yang telah dibuat

Setelah dilakukan surve Fenomena dalam penelitian ini bahwa masih banyak karyawan yang belum memiliki SIA dalam penggunaan laporan keuangan.

Dari uraian diatas, maka penelitian ini bertujuan untuk menganalisis bagaimana implementasi sistem informasi akuntansi untuk menunjang kinerja keuangan pada Forum UMKM Pasaman Barat. Forum UMKM Pasaman Barat sebagian pemilik UMKM masih awam dalam melakukan pencatatan akuntansi baik secara manual maupun terkomputerisasi sehingga tidak dapat ditentukan berapa keuntungan yang diperoleh dari pihak UMKM tersebut.

\section{Tinjauan Literatur}

Menurut Undang-Undang Nomor 20 Tahun 2008 usaha kecil adalah usaha ekonomi produktif yang 
berdiri sendiri, yang dilakukan oleh orang perorangan atau badan usaha yang bukan merupakan anak perusahaan atau bukan cabang perusahaan yang dimiliki, dikuasai atau menjadi bagian baik langsung maupun tidak langsung dari usaha menengah dan usaha besar yang memenuhi kriteria usaha kecil. Usaha Kecil dan Menengah (UKM) merupakan salah satu pelaku yang berperanan penting dalam kebijakan perokonomian suatu negara (Tsalitsa, 2016).

\section{Sistem Informasi Akuntansi}

Pengertian sistem informasi terbagi menjadi tiga bagian, yaitu sistem, informasi dan akuntansi dari tiga hal diatas mempunyai pengertian yang berbeda pula.

Menurut (Sidharta dan Margaret, 2011) sistem merupakan himpunandari bagian-bagian yang saling berhubungan secara bersama-sama mencapai tujuan-tujuan yang sama. Sedangkan menurut (Hutahaean, 2014) Informasi merupakan data yang diolah menjadi bentuk yang lebih berguna dan lebih efisian berarti bagi penerimanyan.

(Bodnar, 2004) menyatakan bahwa sistem informasi akuntansi merupakan kumpulan dari sumber daya yang mampu mengolah data akuntansi menjadi sebuah informasi yang berguna bagi para pengambil keputusan melalui media komputerisasi. Sistem informasi akuntansi adalah suatu sistem yang mengumpulkan, mencatat, menyimpan dan mengolah data untuk menghasilkan informasi bagi pengambil keputusan (Romney, Marshall B., 2015)

\section{Kinerja Keuangan}

kinerja keuangan perusahaan merupakan prestasi yang dicapai perusahaan dalam suatu periode tertentu yang mencerminkan tingkat kesehatan perusahaan tersebut (Sutrisno, 2009:53).

Kinerja keuangan merupakan gambaran dari pencapaian keberhasilan perusahaan dapat diartikan sebagai hasil yang telah dicapai atas berbagai aktivitas yang telah dilakukan. Dapat dijelaskan bahwa kinerja keuangan adalah suatu analisis yang dilakukan untuk melihat sejauh mana suatu perusahaan telah melaksanakan dengan menggunakan aturan-aturan pelaksanaan keuangan secara baik dan benar Fahmi. (2012).

\section{Metodologi Penelitian}

Subjek dari penelitian ini adalah seluruh anggota Forum UMKM sehingga bisa didapat data-data atau informasi yang akan digunakan dan dikelola dalam penelitian ini. Jenis data yang digunakan dalam penelitian ini adalah data primer. Data primer adalah data yang diperoleh langsung dari pihak yang bersangkutan dan juga menggunakan data data kualitatif. Yang dimaksud dengan data kualitatif adalah data yang menggunakan deskriptif dan tidak menggunakan angka dalam penelitian. Pengumpulan data yang dilakukan dalam penelitian ini dilakukan dengan cara melakukan survey lapangan atau tempat yang dijadikan tempat penelitian. Metode penelitian ini menggunakan beberapa metode antara lain interview (wawancara) observasi dan dokumentasi. 


\section{Hasil dan Pembahasan}

Berdasarkan hasil penelitian yang dilakukan menunjukan bahwa penerapan Sistem Informasi Akuntansi di Forum UMKM belum maksimal, diketahui bahwa hanya sedikit bagi UMKM yang menggunakan software sistem informasi keuangan menggunakan Ms. Office khususnya Ms. Excel, bahkan masih banyak yang mengunakan manual book atau pencatatan dilakukan di dalam buku saja. Dimulai dari pencatatan sistem penjualan dan juga pembelian.

\section{IMPLEMENTASI DALAM SISTEM INFORMASI AKUNTANSI (SIA)}

Pada Forum UMKM ini memiliki lebih dari 100 anggota UMKM yang tergabung dalam forum ini, setelah dilakukan penelitian dikehatui bahwa masih banyak anggota Forum yang masih menggunakan Ms. Office khususnya Ms. Excel dan manual book.

Dalam penelitian yang telah dilakukan melalui proses observasi, wawancara dan kelapangan di Forum UMKM sehingga kami memberikan saran dalam melakukan transaksi menggunakan bahasapemrograman visual basic dalam bentuk aplikasi SIA sehingga sistem yang disaran kan ini dapat menunjang laporan keuangan bagi anggota forum UMKM di Pasaman Barat.

\section{USULAN PEMECAHAN MASALAH}

Dari hasil analisa diatas masalah-masalah yang dihadapi oleh UMKM Pasaman Barat terkait dengan pengolahan data penjualan yang sedang berjalan, maka penulis melakukan analisa untuk memecahkan masalah tersebut. Oleh karena itu peneliti memberikan beberapa usulan dalam memecahkan masalah, diantaranya:

Penulis mencoba merancang sistem informasi penjualandengan pemrograman Visual Basic6.0

Dengan pemrograman ini dapat mengurangi kesalahan dalam perhitungan barang, produksi barang. Karena program ini dapat menghitung dengan efektif serta meminimalisir kesalahan yangtimbul.Memudahkan manajemen dalam membuat laporan-laporan secara cepat apabila dibutuhkan langsung bisa dicetak dan dapat mempergunakan informasi dalam pengambilan keputusan dengan cepat.

\section{Sistem Informasi Akuntansi UMKM Pasaman Barat}




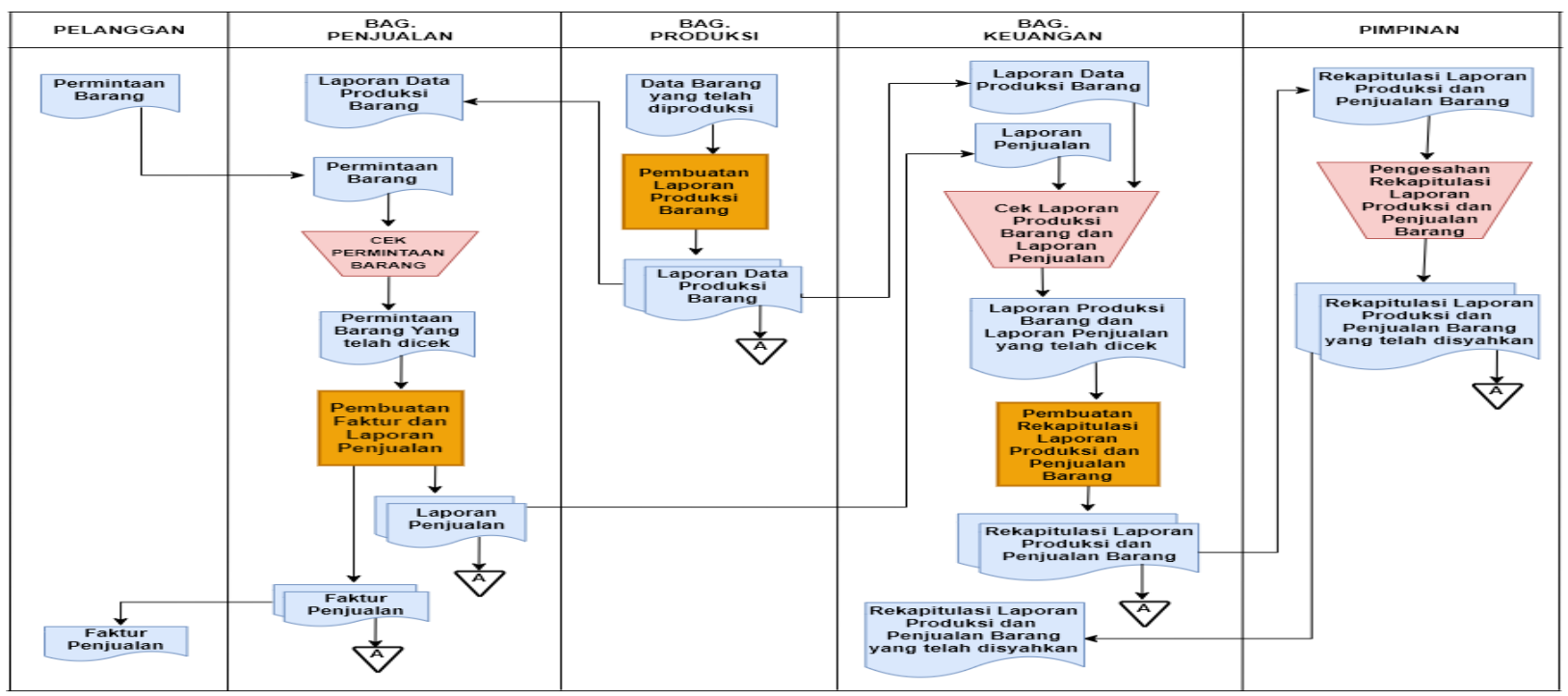

Gambar 1: Aliran Sistem Informasi Baru

\section{IMPLEMENTASI SISTEM}

Pertama kali program dijalankan akan tampil form login, karena menu yang aktif hanya menu login. Program tidak bisa digunakan jika menu login belum di jalankan. Kemudian menginputkan username dan password dengan benar seperti gambar 2 dibawah ini :

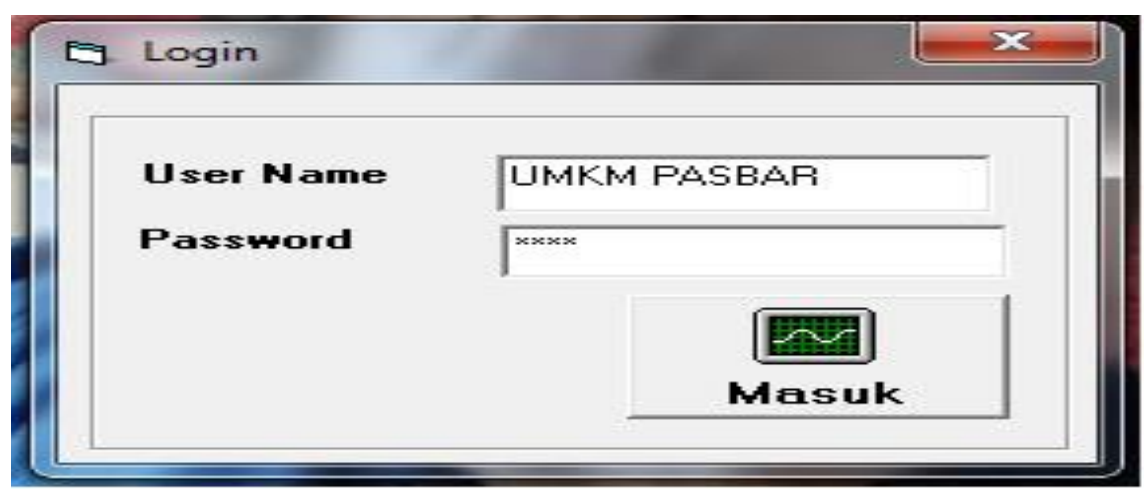

Gambar 2. Form Login

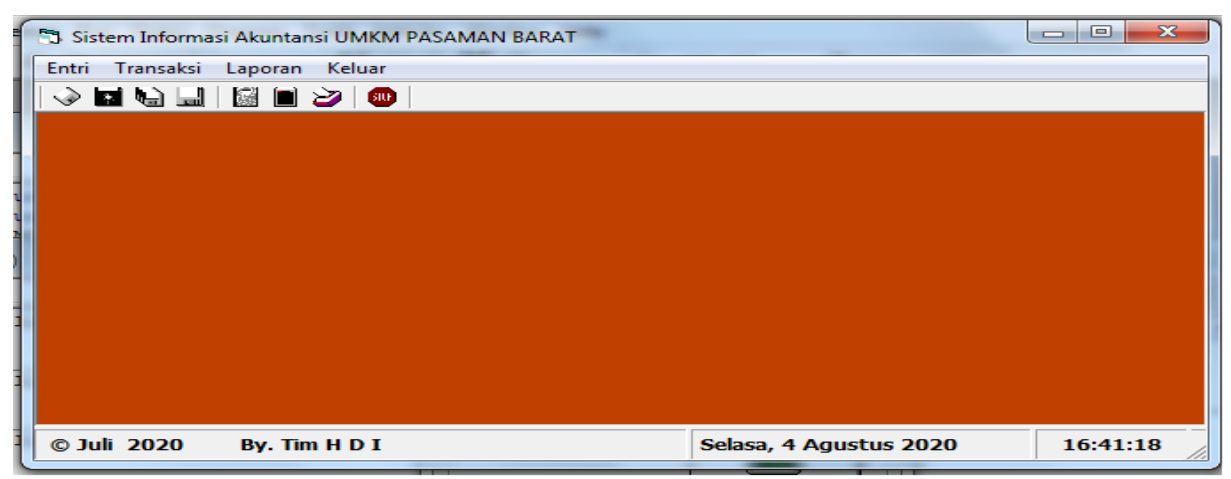

Gambar 3: Menu Utama 
Setelah user berhasil login, maka form selanjutnya yaitu Halaman Menu Utama Program. Form Menu utama berisi Entri, Transaksi dan Laporan seperti terlihat pada gambar 3 diatas, dan masing - masing sub menu akan dijelaskan pada uraian selanjutnya.

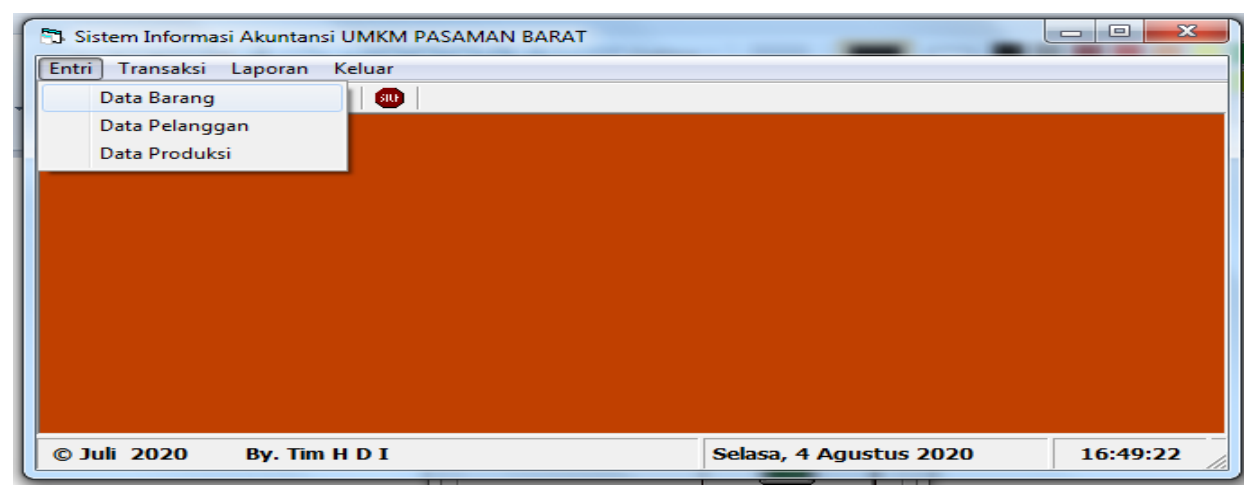

Gambar 4: Menu Entry

Pada Sub Menu Entri terdiri dari Entri Data Barang, Entri Data Pelanggan dan Entri Data Produksi yang dapat dilihat pada gambar 4 diatas.

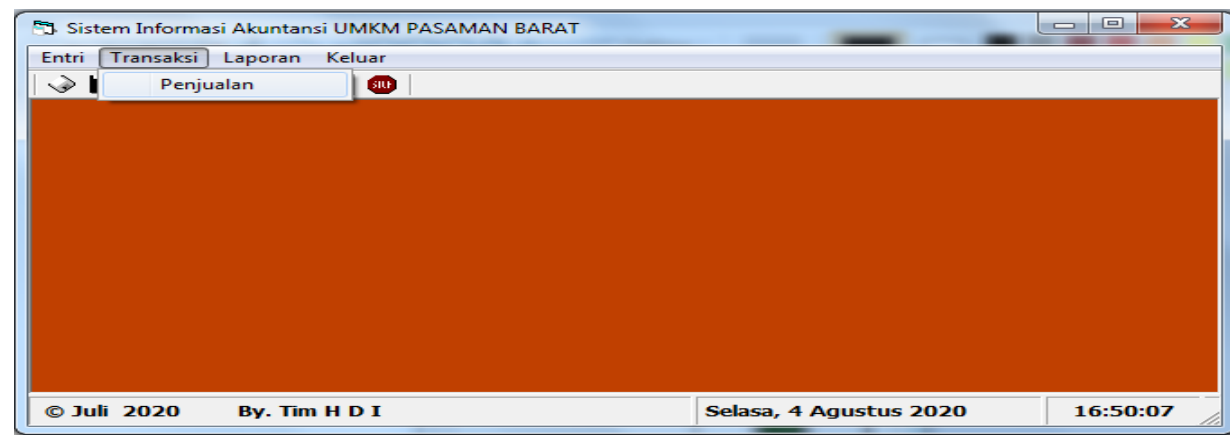

\section{Gambar 5 : Menu Transaksi}

Pada sub menu transaksi terdiri dari input penjualan, seperti yang dapat dilihat pada gambar 5 diatas.

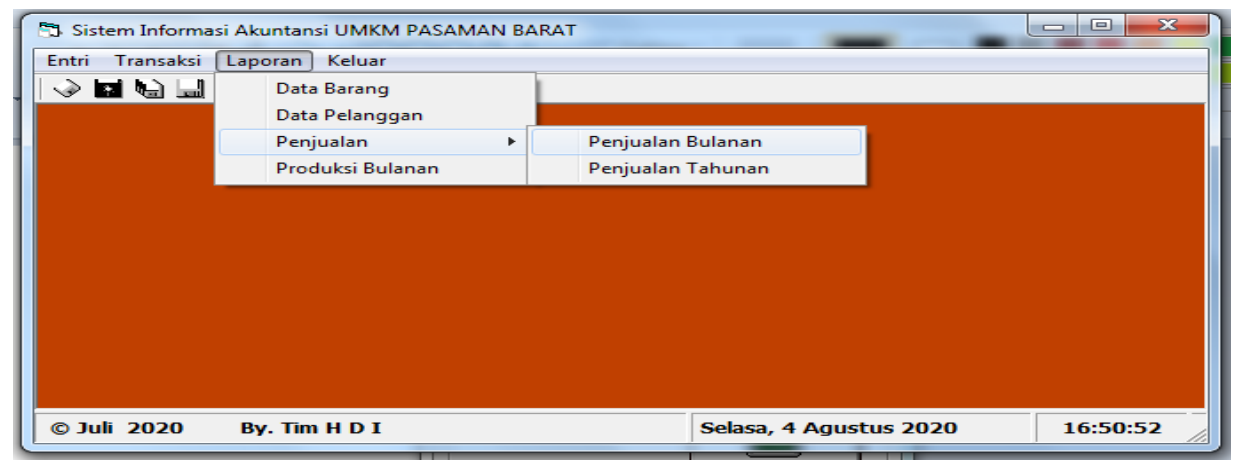

\section{Gambar 6 : Menu Laporan}

Pada sub menu laporan terdiri laporan data barang, laporan data pelanggan, laporan penjualan bulanan dan tahunan, dan laporan produksi bulanan dan tahunan, seperti yang dapat dilihat 
pada gambar 6.

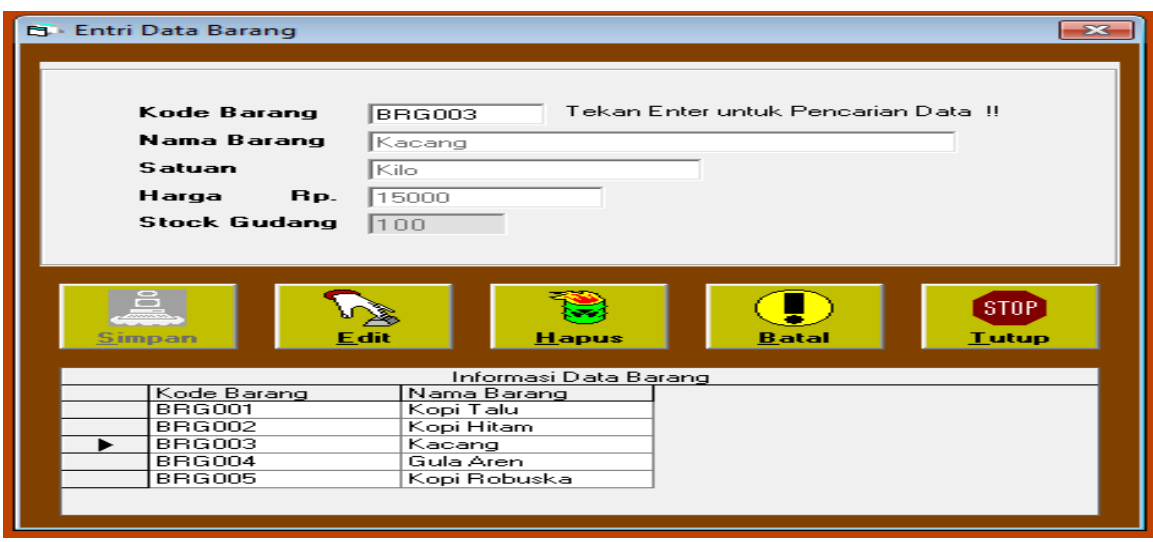

Gambar 7 : Menu Entry Data Barang

Form Entri Data Barang ini menampilkan form untuk menginputkan Data Barang, yaitu : Kode Barang, Nama Barang, Satuan Barang, Harga Barang, dan Stock Barang. seperti yang dapat dilihat pada gambar 7.

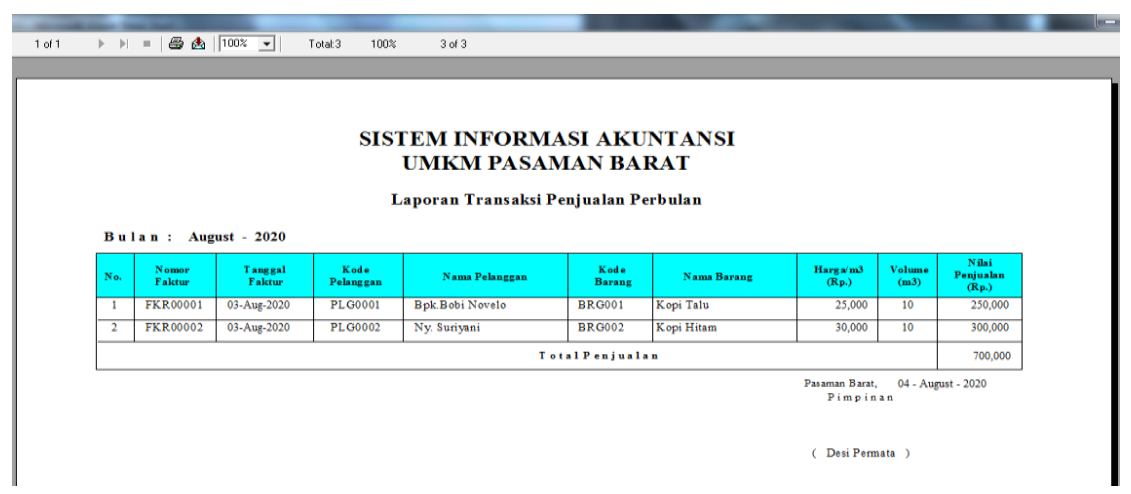

Gambar 8: Laporan Data Penjualan Perbulan

Laporan Data Penjualan Bulanan ini menampilkan form laporan Penjualan untuk setiap bulannya seperti yang dapat dilihat pada gambar 8 .

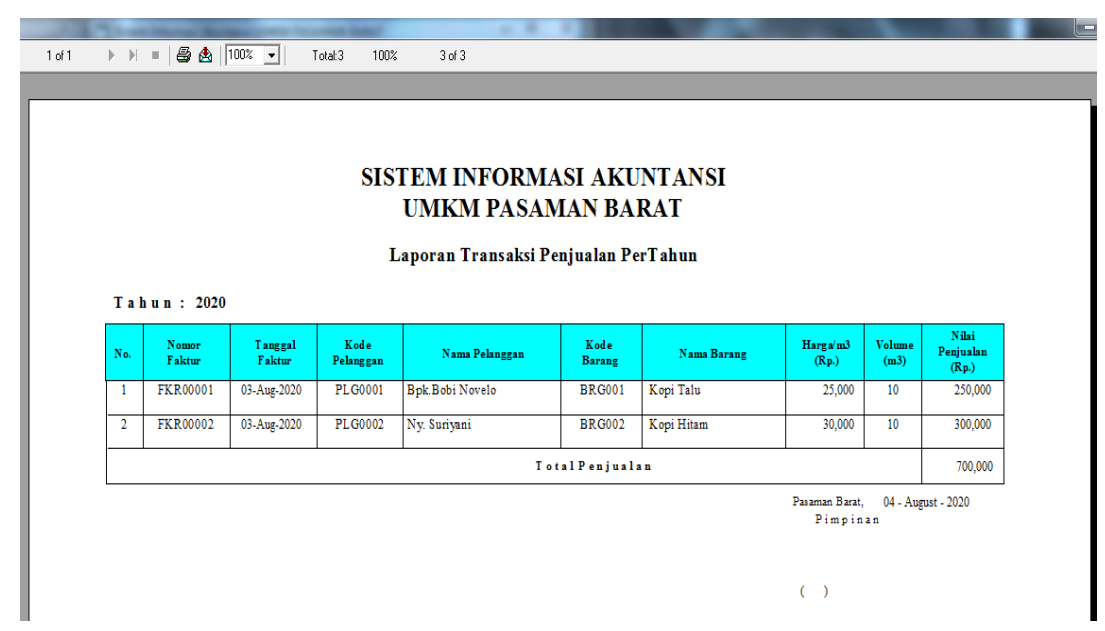

Gambar 9 : Laporan Data Penjualan Pertahun 


\section{DAFTAR PUSTAKA}

[1] Al, E. E. (2012). Edison Et Al. (2012), Manajemen Sumber Daya Manusia Strategi Dan Perubahan Dalam Rangka Meningkatkan Kinerja Pegawai Dan Organisasi. Bandung.

[2] Argacia, J., Sugiarti, Y., \& Harindahyani, S. (2019). Implementasi Sistem Informasi Akuntansi Pada Ukm Dd1, $1-8$.

[3] Awaludin, A. (2015). Awaludin, Ahmad. Ukm Goes Digital. 2015. Pt Gramedia Pustaka Utama, Jakarta.

[4] Bachtiar, Et Al. (2014). Bachtiar, Et Al. 2014. Implementasi Sistem Informasi Akuntansi Bagi Usaha Kecil Dan Menengah Dalam Meningkatkan Akuntabilitas Laporan Keuangan. Jurnal Ekonomi Dan Teknik Informatika, Vol. 2.

[5] Bodnar, G. H. D. W. S. H. (2004). Bodnar, George H. Dan William S. Hopwood. 2004. Sistem Informasi Akuntansi. Edisi 9.

[6] Fitriyah. (2006). Adln Perpustakaan Universitas Airlangga Tesis Analisis Faktor-Faktor Yang Mempengaruhi Hadiah Fitriyah.

[7] Hanafi, M. D. A. H. (2003). Hanafi, Mamduh Dan Abdul Halim. 2003. Analisis Laporan Keuangan. Edisi Revisi. Yogyakarta: Upp Amp Ykpn.

[8] Hutahaean, J. (2014). Hutahaean, Japerson. 2014. Konsep Sistem Informasi, Edisi Pertama. Yogyakarta. Penertbit Deepublish.

[9] Rahmawati, D. (2019). Implementasi Penggunaan Sistem Informasi Akuntansi Umkm Dalam Menghadapi Revolusi Industri 4.0, 09(02), 63-77.

[10] Riza, S. W., \& Maresti, D. (2020). Implementasi Sistem Informasi Akuntansi Pada Usaha Mikro Kecil Menengah (Umkm) Bidang Pendidikan Di Sumatera Barat (Studi Empiris Pada Lembaga Bimbingan Belajar Di Sumatera Barat), 20(1), 126-130. Https://Doi.Org/10.33087/Jiubj.V20i1.819

[11] Romney, Marshall B., P. J. S. (2015). Romney, Marshall B., Paul John Steinbart. 2015. Accounting Information System,13 Th Ed. England: Pearson Education Limited.

[12] Sidharta Dan Margaret, M. (2011). Komitmen Organisasi Terhadap Kepuasan Kerja.Pdf.

[13] Suharnato. (2018). Implementasi Sistem Informasi Dalam Perbaikan Kualitas Laporan Keuangan, 1(2), 46-49.

[14] Suryo. (2008). Suryo. 2008. Genetika Strata 1. Yogyakarta: Gadjah Mada University Press.

[15] Tsalitsa, A. (2016). Media Ekonomi Dan Manajemen Vol. 31 No. 1 Januari 2016, 31(1), 1-13.

[16] Undang-Undang Republik Indonesia Nomor 20 Tahun 2008 Tentang Usaha Mikro, Kecil, Dan Menengah Dan Undang-Undang Republik Indonesia Nomer 21 Tahun 2008 Tentang Perbankan Syari’ah. 